\title{
Knowledge and Experience of Community Health Volunteer (Cadre) on Type 2 Diabetes Mellitus Management in Yogyakarta
}

\author{
Yanuar Primanda*, Desy Ivani Fatah \\ Department of Adult Nursing, School of Nursing, Universitas Muhammadiyah Yogyakarta, Bantul, Indonesia
}

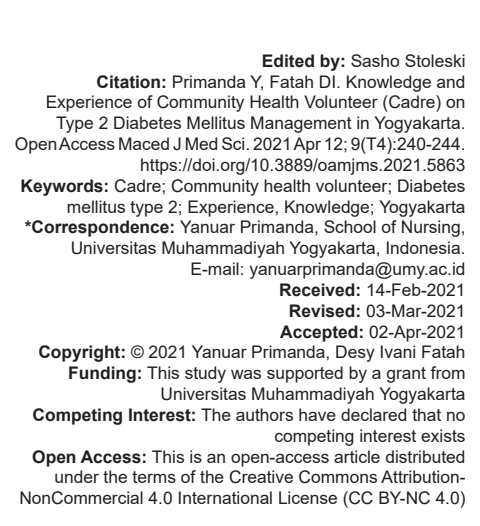

\section{Introduction}

Diabetes mellitus (DM) is one of the chronic metabolic diseases characterized by hyperglycemia due to abnormality of insulin action, insulin secretion, or both and metabolism disturbance of carbohydrate, fat, and protein [1]. The International Diabetes Federation estimated that about $9.3 \%$ of the global population aged 20-79 years are currently living with DM, which accounted for about 463 million [2].

In Indonesia, a national study revealed that about $10.9 \%$ of Indonesia's people live with DM [3]. In Yogyakarta, a province in Java Island, Indonesia, the prevalence of DM is considered high. About $3.1 \%$ of people older than 15 years old have been diagnosed with DM, and this puts Yogyakarta as the top three provinces with the highest prevalence of DM after Jakarta (3.4\%) and East Kalimantan (3.1\%) [3]. In Bantul District, one out of the five districts in Yogyakarta, there were about 15,925 visits to primary health-care centers (Puskesmas) due to diabetes, which puts DM among the top 10 diseases in Puskesmas [4].

Uncontrolled DM can cause either macrovascular or microvascular complications and possible mortality [5], [6]. Furthermore, the number of mortality associated with DM is very high, equivalent to 4.2 million deaths worldwide among adults between 20 and 79 years old [2]. DM care and its related complications can cause economic burdens. Globally, it was estimated that diabetes and its complication cost more than USD 760 billion [2]. Considering those overwhelmed impacts of DM, effective DM management strategies are essential to prevent and delay DM-related complications.

In general, the DM management strategies consist of behavior and psychological management and pharmacologic approaches to achieve DM treatment goals. Health care providers play significant roles in facilitating DM management strategies. Recently, the American Diabetes Association has highlighted the importance of local community resources and their roles in diabetes self-management support for people with DM [7]. They may assist in diabetes self-management education (DSME) and support delivery, especially in underserved communities.

In Indonesia, one of the local community resources is a community health volunteer named cadre or Kader. Cadre is selected from the local community and has been trained to encourage and 
organize community participation in community health empowerment [8]. Further, the Ministry of Health stated that community health empowerment includes preventing and managing non-communicable diseases. The cadre's roles are in charge of facilitating the active participation of community members on community health based on their capacity, facilitating the community members to use the community health facilities, organizing community health facilities, counseling and educating related to community health, recording the empowerment programs in the community, and reporting any local health problems or cases to healthcare providers or Puskesmas [8]. Cadres work closely under the guidance of Puskesmas.

In 2010, the Indonesian government initiated the development of non-communicable diseases integrated development post (Posbindu), a participatory community action run by the Posbindu cadre, which focused on detecting and preventing non-communicable diseases [9]. DM is one of the non-communicable diseases that become a big concern in the Posbindu program. It is expected that each village will have at least one Posbindu and each Posbindu has at least five cadres. In 2019, it was targeted that Posbindu could achieve at least $50 \%$ of total villages in all provinces in Indonesia, and about $43.92 \%$ of Posbindu were established in 2018 [10]. Unfortunately, national data about the number of Posbindu cadre are not available.

Health counseling and education related to non-communicable diseases, including DM, are Posbindu cadre roles [11]. Guideline's book to facilitate learning among the Posbindu cadre to perform their role has been released [12], [13]. Considering the important role of cadre, knowledge and experience of cadre are imperative among the cadre. Knowing the level of knowledge and experience among cadre is beneficial for developing further research to empower cadre.

\section{Methods}

It was a descriptive study to describe community health volunteers' knowledge and experiences (cadre) on type 2 DM management in Yogyakarta. The Lemeshow formula was used to calculate the sample size. With $p=0.05$, sampling error $10 \%$, and $z=1.645,68$ participants were needed in this study. The participants were selected through a convenience sampling technique from five Puskesmas areas in Bantul district with a high number of people with Type 2 DM (T2DM) in their area, including Puskesmas Kasihan 2, Jetis 1, Sedayu 1, Jetis 2, and Imogiri 2. The inclusion criteria were cadres (elderly cadres and Posbindu cadres) who worked in the selected area and willing to participate in the study. The elderly cadres were included instead of Posbindu cadres only due to the limited number of Posbindu cadres in the targeted areas and unavailability of a certain database of Posbindu cadres. The exclusion criteria were cadres who declined their participation in the study. This study was conducted in January-February 2019. Data collections were conducted during monthly cadres meetings, and for those who did not attend the meeting, the researchers visited the cadres' home based on an appointment with cadres.

The demographic characteristics of the cadres were collected using a demographic characteristic questionnaire. The cadres' knowledge and experience on T2DM management were measured by questionnaires that were developed by the researchers.

The knowledge about the T2DM management questionnaire consisted of 9 items with true, false, do not know, and uncertain response rates. Those who answered the question correctly scored 1 . The possible score was 0-9. The level of knowledge was categorized into low (score 0-3), moderate (score 4-6), and high (score 7-9).

The 8-item 4-point Likert scale questionnaire was used to measure experience about T2DM. The response rates were ranged from never (score 1) to routine (score 4 ). The possible score was ranged between 8 and 32 . The experience was categorized into the inadequate experience (score 8-19) and adequate experience (score 20-32).

The questionnaire was validated using the content validity index for an item (ICVI) with three experts, and the questionnaire was considered valid if I-CVI was at least 0.8 [14]. The 9-item knowledge questionnaire and 8-item of experience questionnaire had I-CVI ranged from 0.83 to 1 . The Cronbach alpha test was used to test the questionnaires' reliability, resulting from 0.6 considered reliables [15]. The Cronbach alpha of knowledge questionnaire and experience questionnaire among 20 cadres with the same characteristics of cadres in this study but not participated in the study was 0.70 and 0.84 , respectively.

The descriptive statistics were used to analyze the data. Continuous data were presented with mean (SD), and nominal data were presented with frequency $(\%)$.

This study was approved by the Faculty of Medicine and Health Science, Universitas Muhammadiyah Yogyakarta ethical committee with the number of 597/EP-FKIK-UMY/XII/2018.

\section{Results}

Of the total 68 approached participants, all of them $(100 \%)$ agreed to participate in the study. All of the cadres were women with an average age which 
was 42.91 (8.46) years with the youngest age, and the oldest age was 20 and 64, respectively. The average duration of being cadres was $7.10(6.50)$ years, with 1 year and 33 years as the shortest and longest duration, respectively. More than half of cadres graduated from senior high school (54.4\%), have no employment or housewife $(61.8 \%)$, positioned as member of Posyandul Posbindu (83.8\%), and never received training related to T2DM management (51.5\%) (Table 1).

Table 1: Demographic characteristics of cadres $(n=68)$

\begin{tabular}{ll}
\hline Characteristics & Frequency (\%) \\
\hline Age (year) & $20(29.4)$ \\
$20-39$ & $45(66.3)$ \\
$40-59$ & $3(4.4)$ \\
$\geq 60$ & $3(4.4)$ \\
Education & $5(7.4)$ \\
No education & $8(11.8)$ \\
Primary school & $37(54.4)$ \\
Junior high school & $15(22.1)$ \\
Senior high school & \\
Diploma or higher education & $42(61.8)$ \\
Employment & $26(38.2)$ \\
Housewife/no employment & \\
Employed & $11(16.2)$ \\
Position in Posyandu & $57(83.8)$ \\
Posbindu & \\
Leader & $33(48.5)$ \\
Member & $35(51.5)$ \\
Received training on T2DM management & \\
Yes & \\
No &
\end{tabular}

This study showed that 42 of 68 cadres had a moderate level of knowledge about T2DM management $(61.8 \%)$, and almost a quarter had low knowledge (23.5\%). Furthermore, almost two-thirds of cadres had an inadequate experience related to T2DM management (64.7\%) (Table 2).

Table 2: Level of knowledge and experience of cadres on T2DM management $(n=68)$

\begin{tabular}{ll}
\hline Variables & Frequency (\%) \\
\hline Knowledge & \\
Low & $16(23.5)$ \\
Moderate & $42(61.8)$ \\
High & $10(14.7)$ \\
Experience & \\
$\quad$ Inadequate experience & $44(64.7)$ \\
Adequate experience & $24(35.3)$ \\
\hline T2DM: Type 2 diabetes mellitus. &
\end{tabular}

\section{Discussion}

Cadres are those who selected or trained individuals from the local community. However, they must have available time and willingness to organize and run the Posbindu regularly and Posyandu [16]. Therefore, the majority of cadre are women and housewives or no employment. Posbindu and Posyandu management's guidelines stated that cadre's education level is at least senior high school [11]. In fact, some cadres had a lower education level. It may be because the aspects of willingness and time availability of those who want to be cadres voluntarily are more than the education level itself as the nature of community participatory programs in Indonesia. The idea is that the program is run by the community under the philosophy of "gotong royong," working together under a big family's spirit to achieve the results as wish to improve health status [17].

Training related to T2DM management has never been received by more than half of the cadres in this study. Training of the cadres is primarily the responsibility of the Puskesmas, where the cadres are based [8], [11]. However, the data about the training that has been provided by Puskesmas to cadres are often not available and accessible. Basically, when the Puskesmas conducted training, mostly not all cadres were invited, and the invited cadres might not attend the training. Those who attended the training were expected to disseminate their knowledge to other cadre members.

Indonesian government tried to accommodate the gap between the need for training and the barriers in conducting or attending the training. Education guideline books for Posbindu cadres were released in 2019 by the Directorate of Non-Communicable Diseases Prevention and Control of Indonesia [12], [13]. The books contain important information that should be understood by Posbindu cadres related to chronic diseases, including T2DM. Information about basic knowledge of T2DM, such as the risk factors, complications, and prevention strategies as well as management strategies, were provided in the books except for foot care. A previous study found quite similar results when the majority of the cadres were about 40 years old, graduated from senior high school, and never received training on DM management [18].

The training about DM may influence the moderate level of knowledge among cadres in this study received only by half of the cadres in this study. Training on DM management can effectively increase cadres' knowledge [18]. In addition, the inadequacy of the experience may relate to cadres' confidence. Lack of confidence due to self-perception of insufficient knowledge and incompetence about chronic diseases and Posbindu were considered barriers among Posbindu cadres [19].

The majority of cadres $(89.7 \%)$ answered correctly that oral hypoglycemic agents (OHAs) should be taken routinely based on physician prescription and should not be stopped when people with T2DM felt healthy and did not experience any signs and symptoms of the disease. However, almost half of them thought that although people with T2DM skipped their meals and did not take any foods to replace their meal, they still must take their OHAs (Table 3). Medication adherence is one of the key components in blood glucose control. Nevertheless, skipping meals and taking medication when food ingestion is limited or skipped may cause hypoglycemia [20].

Regarding diabetic foot care, this study found that only $30.9 \%$ of cadres correctly answered that foot moisturizer should not be used in between toes (Table 3). Correct moisturizer application is important to prevent over moist, increasing the risk of fungus 
infestation and infection [21]. In addition, less than $60 \%$ of cadres understand that people with DM must use footwear when going outside or stay inside the home. Appropriate and convenient footwear must be worn anywhere, at home and outside, to prevent injury [22]. However, this practice may be uncommon in Indonesian when many people believe that using footwear at home is considered impolite and not suit for their culture. Therefore, cadres' knowledge regarding footwear might be influenced by their current culture and beliefs.

Table 3: Description of knowledge of cadres on T2DM management $(\mathrm{n}=68)$

\begin{tabular}{ll}
\hline Variables & Correct answer \\
\hline Avoidance of high calories foods & $32(47.1)$ \\
Meal frequency & $35(51.1)$ \\
Exercise frequency & $18(26.5)$ \\
Exercise duration & $52(76.5)$ \\
Types of exercise & $43(63.2)$ \\
Skipping medications and meals & $33(48.5)$ \\
Stop medications while feeling better & $61(89.7)$ \\
Footwear at home & $40(58.8)$ \\
Foot moisturizer application & $21(30.9)$ \\
\hline Data were presented with frequency (\%). T2DM: Type 2 diabetes mellitus.
\end{tabular}

Several factors may contribute to the result of this study, where $<20 \%$ experienced routine activities in DM management (Table 4). Lack of encouragement and supervision from Puskesmas health-care professionals can hinder Posbindu cadres' participation in DM management. In general, most of the Posbindu cadres are laypeople without any formal health education. With limited knowledge and skills related to the complexity of chronic diseases and their management, adequate and efficient training, encouragement, and supervision from health care professionals are essential.

Table 4: Description of experience of cadre on T2DM management $(n=68)$

\begin{tabular}{lllll}
\hline Variables & Never & Occasionally & Often & Routine \\
\hline Blood glucose measurement & $20(29.4)$ & $32(47.2)$ & $8(11.8)$ & $8(11.8)$ \\
Provide SMBG education & $9(13.2)$ & $33(48.5)$ & $19(27.9)$ & $7(10.3)$ \\
Provide diet education & $8(11.8)$ & $38(52.9)$ & $18(26.5)$ & $6(8.8)$ \\
$\begin{array}{l}\text { Provide smoking cessation education } \\
\text { Encourage routine exercise }\end{array}$ & $20(29.4)$ & $23(33.8)$ & $18(26.5)$ & $7(10.3)$ \\
$\begin{array}{l}\text { Encourage to consume healthy food } \\
\text { to prevent T2DM }\end{array}$ & $9(13.2)$ & $26(38.2)$ & $23(33.8)$ & $10(14.7)$ \\
$\begin{array}{l}\text { Provide foot care education } \\
\text { Provide medication education }\end{array}$ & $19(27.9)$ & $31(45.2)$ & $22(32.4)$ & $11(16.2)$ \\
Data were presented with frequency (\%). SMBG: Self-monitoring blood glucose. T2DM: Type 2 diabetes & & & \\
\hline
\end{tabular}

Another barrier may be related to facilities and education materials. In performing routine blood glucose measurements, Posbindu cadres need glucometer and all necessary equipment, which may not be available in Posbindu. Education media and materials are also not always available as the cadres may be unable to develop it. Standardized education materials developed by health-care professionals and used plain language may benefit cadres and the members of Posbindu.

\section{Conclusion and Recommendation}

Posbindu cadres had an essential role in DM management. Their position as local community resources should be empowered to support DSME among people with T2DM. This study showed that knowledge of cadres was at a moderate level with inadequate experience. Puskesmas and government should consider the importance of cadres' roles and develop effective strategies to escalate cadres' knowledge and experience through training, encouragement, supervision, and appropriate facilities.

Further research is needed to explore the barriers or challenges and enablers of cadre in preforming their roles, especially in facilitating people with chronic diseases self-management. Further, the effectiveness of training program which facilitates the improvement of knowledge and skills of cadres needs to be investigated. In the end, standardized training protocols for cadres which implemented nationally may beneficial for cadres and people with chronic diseases.

\section{Acknowledgment}

This study was supported by a research grant from Universitas Muhammadiyah Yogyakarta. The researchers thank the cadres and Puskesmas Kasihan 2, Jetis 1, Sedayu 1, Jetis 2, and Imogiri 2 for their support and efforts to participate in this research.

\section{References}

1. World Health Organization. Classification of Diabetes Mellitus; 2019. Available from: https://www.apps.who.int/iris/ handle/10665/325182. [Last accessed on 2020 Aug 30].

2. International Diabetes Federation. IDF Diabetes Atlas. $9^{\text {th }}$ ed. Brussels, Belgium: International Diabetes Federation; 2019. Available: https://www.diabetesatlas.org/upload/resources/ material/20200224_151105_IDFATLAS9e-final-web.pdf. [Last accessed on 2020 Mar 02].

3. Ministry of Health of the Republic of Indonesia. National Report of Basic Health Research 2018. Jakarta: Ministry of Health of the Republic of Indonesia; 2018. https://doi.org/10.25133/ jpssv27n1.003

4. Health profile of Bantul District; 2020. Available from: https:// www.dinkes.bantulkab.go.id/filestorage/dokumen/2020/05/ Narasi\%20Profil\%20Kesehatan\%202020.pdf. [Last accessed on 2020 Sep 14]

5. Chawla A, Chawla R, Jaggi S. Microvasular and macrovascular complications in diabetes mellitus: Distinct or continuum? Indian J Endocrinol Metab. 2016;20(4):546-51. https://doi. org/10.4103/2230-8210.183480

PMid:27366724

6. Papatheodorou K, Banach M, Bekiari E, Rizzo M, Edmonds M. Complications of diabetes 2017. J Diabetes Res. 2018;2018:3086167. https://doi.org/10.1155/2018/3086167 PMid:29713648

7. American Diabetes Association. 1. Improving care and promoting health in populations: Standards of medical care in diabetes- 2020. Diabetes Care. 2020;43(Suppl 1):S7-S13. 
https://doi.org/10.2337/dc20-s001

\section{PMid:31862744}

8. Ministry of Health of the Republic of Indonesia. Empowering Community in Health Sector; 2019. Available from: http:// www.hukor.kemkes.go.id/uploads/produk_hukum/PMK_ No_8_Th_2019_ttg_Pemberdayaan_Masyarakat_Bidang_ Kesehatan.pdf. https://doi.org/10.26891/jkm.v1i1.20. [Last accessed on 2021 Feb 25].

9. Ministry of Health of the Republic of Indonesia. Strategic Plans of Ministry of Health 2020-2015: Ministry of Health of the Republic of Indonesia Decision Number HK. 03.01/60///2010;2010. Available from: https://www.extranet.who.int/countryplanningcycles/sites/ default/files/country_docs/Indonesia/indonesian_minstry_of health_strategic_plan_2010-2014.pdf. [Last accessed on 2020 Jan 03]. https://doi.org/10.7454/epidkes.v1i1.1311

10. Directorate of Non-communicable Diseases Prevention and Control of Indonesia. P2PTM Programs and Indicators; 2020. Available from: http://www.p2ptm.kemkes.go.id/profil-p2ptm/ latar-belakang/program-p2ptm-dan-indikator. [Last accessed on 2020 Sep 20].

11. Directorate of Non-communicable Diseases Prevention and Control of Indonesia. Technical Guideline of Non-Communicable Diseases Integrated Development Post (Posbindu PTM); 2012. Available: http://www.p2ptm.kemkes.go.id/uploads/2016/10/ Petunjuk-Teknis-Pos-Pembinaan-Terpadu-Penyakit-TidakMenular-POSBINDU-PTM.pdf. [Last accessed on 2020 Sep 20]. https://doi.org/10.7454/epidkes.v1i2.1805

12. Directorate of Non-Communicable Diseases Prevention and Control of Indonesia. Pocket Book of Posbindu Cadre; 2019. Available from: http://www.p2ptm.kemkes.go.id/uploads/ VHcrbkVobjRzUDN3UCs4eUJ0dVBndz09/2019/03/Buku_ Pintar_Kader_POSBINDU.pdf. [Last accessed on 2020 Sep 20].

13. Directorate of Non-communicable Diseases Prevention and Control of Indonesia. Technical Guideline of Integrated Development Post (Posbindu) for Cadre; 2019. Available from: http://www.p2ptm.kemkes.go.id/uploads/ VHcrbkVobjRzUDN3UCs4eUJ0dVBndz09/2019/03/Petunjuk Teknis_POSBINDU_Bagi_Kader.pdf. [Last accessed on 2020 Sep 20].
14. Polit DF, Beck CT. The content validity index: Are you sure you know what's being reported? Critique and recommendations. Res Nurs Health. 2006;29(5):489-97. https://doi.org/10.1002/ nur.20147 PMid: 16977646

15. Ursachi G, Horodnic IA, Zait A. How reliable are measurement scales? External factors with indirect influence on reliability estimators. Procedia Econ Finance. 2015;20:679-86. https://doi. org/10.1016/s2212-5671(15)00123-9

16. Ministry of Home Affairs of the Republic of Indonesia Guideline in Integrating Basic Social Services in Integrated Post Services (Pos Pelayanan Terpadu); 2011. Available from: https://www.peraturan.bkpm.go.id/jdih/userfiles/batang/ Permendagri_19_2011.pdf. [Last accessed on 2021 Feb 25].

17. Soedirham O. Integrated services post (Posyandu) as sociocultural approach for primary health care issue. Natl Public Health J. 2012;l:195-8. http://dx.doi.org/10.21109/kesmas. v7i5.40

18. Ernawati E. Improving knowledge and skills on diabetes management through diabetes management training among health cadres. J Keperawatan Indones. 2012;15(2):123-8. https://doi.org/10.7454/jki.v15i2.37

19. Hastuti NM, Puspitasari R, Sugiarsi S. The roles of health cadres in non-communicable Posbindu program in Puskesmas Jaten. J IImiah Matern. 2019;3(2):57-61. https://doi.org/10.31227/osf. io/9bpt7

20. Kreider KE, Padilla BI, Pereira K. Hypoglycemia in diabetes: Challenges and opportunities in care. J Nurse Pract. 2017;13(3):228-34.

21. National Institute of Diabetes and Digestive and Kidney Diseases. Diabetes and Foot Problems; 2017. Available from: https://www.niddk.nih.gov/health-information/diabetes/ overview/preventing-problems/foot-problems. [Last accessed on 2020 Sep 20].

22. IWGDF. IWGDF Guidelines on the Prevention and Management of Diabetic Foot Diasease; 2019. Available from: https://www. iwgdfguidelines.org/wp-content/uploads/2019/05/IWGDFGuidelines-2019.pdf. [Last accessed on 2020 Mar 25]. https:// doi.org/10.33235/wpr.27.3.144 